\title{
Generation of Epichloë Strains Expressing Fluorescent Proteins Suitable for Studying Host-Endophyte Interactions and Characterisation of a T-DNA Integration Event
}

\author{
Inoka K. Hettiarachchige ${ }^{1}$, Emma J. Ludlow ${ }^{1}$, Piyumi N. Ekanayake ${ }^{1}$, Natasha D. Brohier ${ }^{1}$, \\ Sareena Sahab ${ }^{1}$, Timothy I. Sawbridge ${ }^{1,2}$, German C. Spangenberg ${ }^{1,2}$ and \\ Kathryn M. Guthridge ${ }^{1, *}$ \\ 1 Agriculture Victoria, AgriBio, Centre for AgriBioscience, Bundoora, VIC 3083, Australia; \\ inoka.hettiarachchige@agriculture.vic.gov.au (I.K.H.); emma.ludlow@agriculture.vic.gov.au (E.J.L.); \\ piyumi.ekanayake@agriculture.vic.gov.au (P.N.E.); natasha.brohier@agriculture.vic.gov.au (N.D.B.); \\ sareena.sahab@agriculture.vic.gov.au (S.S.); tim.sawbridge@agriculture.vic.gov.au (T.I.S.); \\ german.spangenberg@agriculture.vic.gov.au (G.C.S.) \\ 2 School of Applied Systems Biology, La Trobe University, Bundoora, VIC 3083, Australia \\ * Correspondence: kathryn.guthridge@agriculture.vic.gov.au; Tel.: +61-3-9032-7062
}

Received: 27 November 2019; Accepted: 24 December 2019; Published: 27 December 2019

\begin{abstract}
Methods for the identification and localisation of endophytic fungi are required to study the establishment, development, and progression of host-symbiont interactions, as visible reactions or disease symptoms are generally absent from host plants. Fluorescent proteins have proved valuable as reporter gene products, allowing non-invasive detection in living cells. This study reports the introduction of genes for two fluorescent proteins, green fluorescent protein (GFP) and red fluorescent protein, DsRed, into the genomes of two distinct perennial ryegrass (Lolium perenne L.)-associated Epichloë endophyte strains using A. tumefaciens-mediated transformation. Comprehensive characterisation of reporter gene-containing endophyte strains was performed using molecular genetic, phenotypic, and bioinformatic tools. A combination of long read and short read sequencing of a selected transformant identified a single complex T-DNA insert of 35,530 bp containing multiple T-DNAs linked together. This approach allowed for comprehensive characterisation of T-DNA integration to single-base resolution, while revealing the unanticipated nature of T-DNA integration in the transformant analysed. These reporter gene endophyte strains were able to establish and maintain stable symbiotum with the host. In addition, the same endophyte strain labelled with two different fluorescent proteins were able to cohabit the same plant. This knowledge can be used to provide the basis to develop strategies to gain new insights into the host-endophyte interaction through independent and simultaneous monitoring in planta throughout its life cycle in greater detail.
\end{abstract}

Keywords: Epichloë; endophyte; reporter gene; green fluorescent protein; DsRed; A. tumefaciens-mediated transformation; transformants; T-DNA integration; sequencing

\section{Introduction}

Asexual endophytes from the genus Epichloë (previously Neotyphodium), are strictly seed-transmitted endophytic symbionts of cool-season grasses (Poaceae, sub-family Pooideae) characterised by a life-cycle wholly confined to the host plant $[1,2]$. The relationships between asexual Epichloë species and their grass hosts are often mutualistic in nature [3]. Endophyte infection can impart environmental stress tolerance and protection from herbivory, thus markedly enhancing 
host survival. The latter property is attributable to production of bioprotective alkaloid compounds, including ergot alkaloids, pyrrolopyrazines (such as peramine), aminopyrrolizidines (such as lolines), and indole-diterpenes (including lolitrems and epoxy-janthitrems) [3-6]. Conversely, the endophyte obtains nutrition and shelter from the host [3]. Several taxa of asexual Epichloë fungal endophytes have been found to form associations with perennial ryegrass, the most important pasture grass species for temperate grassland agriculture, including E. festucae var. lolii (LpTG-1, Lolium perenne taxonomic group 1), LpTG-2, LpTG-3, and LpTG-4, respectively [7,8].

A considerable number of studies have been conducted describing the production of alkaloids by endophyte-forage grass associations, primarily due to the economic impact of deleterious metabolites on agricultural systems [9]. However, much less is known about other aspects of the association, such as host colonisation, cross species compatibility, capacity for co-existence of multiple endophytes of the same and different species within the same host, and subsequent vegetative and intergenerational stability. Methods for identification and localisation of endophytes are required in order to study the establishment, development, and progression of host-symbiont interactions, as visible reactions or disease symptoms are generally absent from host plants [10]. Fluorescent proteins such as GFP and DsRed are extremely useful markers in living cells and organisms [11]. Fungal strains that express these fluorescent proteins provide the ability to directly visualise biological processes, such as host colonisation and establishment of associations, without obvious effects on fungal growth [12]. Complementary use of these reporter proteins is highly advantageous, as conventional fluorescence microscopy can effectively distinguish between co-expressed DsRed and GFP, due to considerable differences in spectral properties, in contrast to different GFP variants in multicolour experiments [13]. Several studies of genetically modified Epichloë endophytes expressing GFP have been reported [14-16]. However, reporter gene-containing endophytes of different taxa expressing both GFP and DsRed and capable of colonising perennial ryegrass have not been described. Strains of this kind would be highly valuable for analysis of processes involved in various aspects of the host-endophyte association, such as time-course analysis of endophyte host colonisation, interactions between co-inoculated endophytes, and the possibility of observing in planta parasexual events based on inter-strain hyphal fusion.

Molecular characterisation of fungi that express fluorescent proteins have been the subject of extensive study [17-19]. PCR-based techniques and Southern hybridisation analysis have been used for identification of transgene-flanking sequences in several fungal species [20-22]. However, these techniques are of limited use for identification of multiple complex patterns of T-DNA integrations, or incomplete sequences [23-25]. Therefore, until recently, limited information was available on the patterns and sites of T-DNA integration in fungi following A. tumefaciens-mediated transformation, although some characterisation of T-DNA insertion events based on PCR and Southern hybridisation has been reported for Saccharomyces cerevisiae, Leptosphaeria maculans, Magnaporthe oryzae, Histoplasma capsulatum, Fusarium oxysporum, and Cryptococcus neoformans var. neoformans [20,21,26-28].

High-throughput second-generation sequencing can be used to effectively and accurately determine exact transgene copy number, presence or absence of the vector backbone, as well as the location of specific transgene integration sites [29,30]. However, generation of accurate genome assemblies, with large repeat structures, using short read sequencing is challenging [31]. In contrast, long read sequencing such as the Oxford Nanopore Technologies MinION have the ability to overcome these limitations and have been used to investigate complex T-DNA integration patterns in plants recently [31]. Undesired, complex, and unanticipated T-DNA integrations have been frequently observed for transgenic plants; precise and detailed analysis of the genome following any form of genetic modification is critical for commercial, regulatory, and research purposes [31,32]. Comprehensive characterisation of changes in genome configuration following T-DNA integration is also important as this may also impact expression of the transgene [33]. The importance has become further emphasized considering the use of $A$. tumefaciens-mediated transformation methods for genome editing experiments [31]. Use of long read sequencing to characterise T-DNA integration events in fungi, including endophytes, has not been reported and hence, represents a novel application of this 
technology for asexual Epichloë fungal endophytes. This study offers new perspectives to understand the complex patterns of T-DNA integration in fungal genomes.

The present study describes the successful generation of GFP and DsRed expressing asexual Epichloë endophyte strains, henceforth referred to as endophytes, belonging to different representative taxa, L $p$ TG-3 (strain NEA12) and L $p$ TG-4 (strain E1), which provide bioprotective properties to the host plant against invertebrate herbivores, likely through production of epoxy-janthitrems $[6,8,34]$. This study also reports comprehensive characterisation of these reporter gene-containing Epichloë endophyte strains using molecular genetic, phenotypic, and bioinformatic tools. The ability of these reporter endophytes to establish a successful symbiotum with the host was studied. Furthermore, co-inoculation studies demonstrated the co-existence ability of endophytes expressing GFP and DsRed from the same taxon in the same host. The results obtained in this study strongly suggest the applicability of these reporter gene-containing endophyte strains to better understand host-symbiont association. The outcomes of the first use of third-generation long-range DNA sequencing to identify complex T-DNA integration events in fungal genomes provide a significant advance, which may be further explored to understand the intricacies of $A$. tumefaciens-mediated transformation of fungi.

\section{Materials and Methods}

\subsection{Microbial Culture Conditions}

Properties of the selected endophyte strains are summarised in Table 1. Cultures of NEA12 and E1 were grown either on potato dextrose agar (PDA; Sigma-Aldrich, St. Louis, MO, USA), or in PDB at $22{ }^{\circ} \mathrm{C}$ in the dark for a period of 7-10 days, depending upon growth rate. The AGL1 and LBA 4404 strains of $A$. tumefaciens which were used for transformation, and Escherichia coli strain DH5 $\alpha$ (Thermo Fisher Scientific, Walthman, MA, USA), which was used during construction and maintenance of plasmid constructs, were grown at 28 and $37^{\circ} \mathrm{C}$, respectively, on either LB (Luria-Bertani) agar (5 g yeast extract, $10 \mathrm{~g}$ tryptone, $10 \mathrm{~g} \mathrm{NaCl}$ in $1 \mathrm{~L}$ of $\mathrm{ddH}_{2} \mathrm{O}$ ) plates or in $\mathrm{LB}$ broth. PDA and LB media were supplemented with appropriate antibiotics as necessary [35].

Table 1. Properties of selected asexual Epichloë endophytes used for transgenic modification.

\begin{tabular}{|c|c|c|}
\hline Endophyte Strain & NEA12 & E1 \\
\hline Taxon $^{\mathrm{a}}$ & LpTG-3 & LpTG-4 \\
\hline Origin $b$ & Lolium perenne (France) & F. rubra ssp. commutate (unknown) \\
\hline Ploidy Level ${ }^{\mathrm{c}}$ & haploid & haploid \\
\hline Mating Type Idiomorph ${ }^{\mathrm{d}}$ & MTB & MTA \\
\hline Number of Mating Type Genes e & 1 & 3 \\
\hline Alkaloid Biosynthesis Profile ${ }^{f}$ & epoxy-janthitrems & epoxy-janthitrems \\
\hline Growth Rate $\mathrm{g}$ & Slow & Fast \\
\hline
\end{tabular}

$\mathrm{a}, \mathrm{b}, \mathrm{c}, \mathrm{d}, \mathrm{e}, \mathrm{f}$ [8]. ${ }^{\mathrm{g}}$ Compared by mycelial growth on PDA in $22^{\circ} \mathrm{C}$ in the dark.

\subsection{Construction of Vectors Containing Reporter Genes}

Gene cassettes including the constitutive Aspergillus nidulans glyceraldehyde-3-phosphate dehydrogenase promoter $(g p d \mathrm{P})$ and the $A$. nidulans tryptophan biosynthesis terminator $(\operatorname{tr} p C \mathrm{~T})$, for cloning of the first reading frame A (RFA-A) cassette; the hygromycin B resistance gene $(h p h)$ under the control of the $A$. nidulans $\operatorname{trp} C$ promoter $(\operatorname{trp} C \mathrm{P})$ and terminator; and reporter genes including DsRed (DsRed-Express 736 bp, gb|DQ232603.1|), sgfp (gb|EF090408.1|), egfp (gb|HQ259114.1|) containing attB1 and attB2 sites were synthesised and obtained from GeneArt, Regensburg, Germany. The Gateway ${ }^{\mathrm{TM}}-$ enabled destination vector (pEND0002) was constructed through modifications of the T-DNA region of pPZP200 [36] by cloning the $2.1 \mathrm{~kb} \mathrm{XbaI/KpnI} \mathrm{fragment} \mathrm{containing} \mathrm{the} h p h$ expression cassette and $2.9 \mathrm{~kb} g p d \mathrm{P}$-(RFA-A)-trpCT cassette (Invitrogen, Thermo Fisher Scientific, Walthman, MA, USA) as previously described in [35]. 
The $779 \mathrm{bp}$ fragments corresponding to the reporter genes sgfp and egfp were excised from vectors pMA4 and pMA5, respectively, using the SacI and KpnI restriction enzyme sites. The DsRed gene, containing attB1 and attB2 sites, was excised from the pMA3 vector by co-digestion with the restriction endonucleases $A s c \mathrm{I}$ and PacI. DsRed, egfp, and sgfp gene fragments containing attB1 and attB2 sites were cloned into the pDONR221 vector using BP clonase following the manufacturer's recommended method (Invitrogen, Thermo Fisher Scientific, Walthman, MA, USA) generating entry clones designated pEND0003, pEND0004, and pEND0005, respectively. The entry clones pEND003, pEND004, and pEND005 were combined with the destination vector pEND0002 using a LR clonase reaction following the manufacturer's recommended method (Invitrogen, Thermo Fisher Scientific, Walthman, MA, USA), to generate the final expression vectors pEND-DsRed, pEND-egfp, and pEND-sgfp, respectively.

T-DNA regions of all expression clones were sequence verified by Sanger sequencing using oligonucleotides; RFA-R1-F (5'-ACAAGGTCGTTGCGTCAGTC-3'), RFA-R1-R (5'-ACATTATACGAGCCGGAAGC-3'), RFA-R2-F (5'-TTATACGCAAGGCGACAAGG-3'), RFA-R2-R (5'-GTAAGCCGGATCCACGCG-3'), PZP-TR-F (5'-CCCACTCCACATCTCCACTC-3'), PZP-TR-R (5'-AAACGCTCTTTTCTCTTAGG-3' ${ }^{\prime}$ ), PZP-TL-F (5' -TGTGGTGTAAACAAATTGACG-3'), PZP-TL-R (5'-TTCAATTCGGCGTTAATTCAG-3'), gpdP-trpCT-F (5'-ATGTCCTCGTTCCTGTCTGC-3') and gpdP-trpCT-R (5'-GTCAGCCAACTGCAAACAGA-3').

Details of all plasmids designed and constructed in this study are summarised in Table S1.

\subsection{Sensitivity of Non-Transgenic Endophyte Mycelia to Hygromycin B}

The sensitivity of non-transformed endophyte mycelia to treatment with hygromycin B were determined by plating $400 \mu \mathrm{L}$ of liquid culture onto PDA plates containing increasing concentrations of antibiotic (50,100, 150, 200, 250, and $300 \mu \mathrm{g} / \mathrm{mL})$ as previously described [35].

\subsection{Transformation}

\subsubsection{A. tumefaciens-Mediated Transformation}

A. tumefaciens-mediated transformation of endophyte strains NEA12 and E1 was performed using A. tumefaciens cells (AGL1 and LBA 4404) as previously described in [35]. Control experiments were performed by co-cultivation of endophyte mycelia with strains of $A$. tumefaciens that had not been transformed with the plasmid vectors.

\subsubsection{Mitotic Stability of Transformed Endophytes}

Mitotic stability of putative endophyte transformants obtained from each vector (appearing 2-4 weeks after $A$. tumefaciens-mediated transformation) and protoplast-derived transformants was determined by sub-culturing five successive times, every 2-3 weeks, alternating between media containing and lacking $200 \mu \mathrm{g} / \mathrm{mL}$ hygromycin B as previously described in [35].

\subsubsection{Molecular Analysis of Transformed Endophytes}

Putative transformants were confirmed by PCR analysis. Genomic DNA was extracted by an optimised procedure described by [37] using 30-60 mg of freeze-dried endophyte mycelium harvested by filtration of liquid culture through Miracloth. PCR analysis was performed using the following primer pairs: GFPF (5'-CCTGAAGTTCATCTGCACCA-3'), GFPR (5'-TCAGGTAGTGGTTGTCG-3'), DsRedF ( $5^{\prime}$-TCCAAGGTGTACGTGAAGCA-3'), DsRedR (5'-TGGTGTAGTCCTCGTTGTGG-3'), hphF (5'-GATGTTGGCGACCTCGTATT-3'), and hphR (5'-GAATTCAGCGAGAGCCTGAC-3'). PCR cycling conditions consisted of an initial denaturation cycle of $10 \mathrm{~min}$ at $95^{\circ} \mathrm{C}$, followed by 30 cycles with $30 \mathrm{~s}$ denaturation $\left(95^{\circ} \mathrm{C}\right), 30 \mathrm{~s}$ annealing $\left(59^{\circ} \mathrm{C}\right)$, and $1 \mathrm{~min}$ polymerisation $\left(72^{\circ} \mathrm{C}\right)$. 


\subsection{Preparation and Regeneration of Fungal Protoplasts}

Preparation and regeneration of protoplasts was performed as previously described in [6]. In brief, mycelia were harvested and washed 3 times with $30 \mathrm{~mL}$ of sterile $\mathrm{ddH}_{2} \mathrm{O}$ and $10 \mathrm{~mL}$ of $\mathrm{OM}$ buffer (1.2 $\mathrm{M} \mathrm{MgSO}_{4} .7 \mathrm{H}_{2} \mathrm{O}, 10 \mathrm{mM} \mathrm{Na}_{2} \mathrm{HPO}_{4}, 100 \mathrm{mM} \mathrm{NaH}_{2} \mathrm{PO}_{4} .2 \mathrm{H}_{2} \mathrm{O}, \mathrm{pH}$ 5.8). Freshly prepared 10 $\mathrm{mg} / \mathrm{mL}$ Glucanex (30 mL) (Sigma-Aldrich, St. Louis, MO, USA) in OM was added and incubated for $18 \mathrm{~h}$ at $30{ }^{\circ} \mathrm{C}$ with gentle shaking $(80 \mathrm{rpm})$. Protoplasts were filtered and overlayed with $2 \mathrm{~mL}$ of ST buffer (0.6 M sorbitol, $100 \mathrm{mM}$ Tris- $\mathrm{HCl}, \mathrm{pH}$ 8.0) and centrifuged (Avanti ${ }^{\circledR} \mathrm{J}-25 \mathrm{I}$; Beckman Coulter, Brea, CA, USA) (5000 rpm for $5 \mathrm{~min}$ at $4{ }^{\circ} \mathrm{C}$ ). Following centrifugation, the protoplasts were removed carefully and STC buffer ( $1 \mathrm{M}$ sorbitol, $50 \mathrm{mM} \mathrm{CaCl} 2 \cdot 2 \mathrm{H}_{2} \mathrm{O}, 50 \mathrm{mM}$ Tris-HCl, pH 8.0) (5 mL) was added. Protoplast pellets were pooled with $5 \mathrm{~mL}$ of STC buffer and centrifugation was repeated (5000 rpm for $5 \mathrm{~min}$ at $4^{\circ} \mathrm{C}$ ). The final protoplast pellet was re-suspended in $500 \mu \mathrm{L}$ of STC buffer.

Serial dilutions of fresh protoplast preparations were made with $40 \%(w / v)$ PEG solution $(40 \%$ $(w / v)$ PEG 4000, $1 \mathrm{M}$ sorbitol, $50 \mathrm{mM}$ Tris- $\mathrm{HCl}, \mathrm{pH} 8.0,50 \mathrm{mM} \mathrm{CaCl}$ ) in a total volume of $1 \mathrm{~mL}$, followed by gentle mixing and incubation at room temperature for $15 \mathrm{~min}$. Regeneration of protoplasts was performed by spreading molten $\left(50{ }^{\circ} \mathrm{C}\right) 0.4 \% \mathrm{RG} \mathrm{II}(5 \mathrm{~mL})\left(304 \mathrm{~g} / \mathrm{L}\right.$ sucrose, $1 \mathrm{~g} / \mathrm{L} \mathrm{KH}_{2} \mathrm{PO}_{4}, 1 \mathrm{~g} / \mathrm{L}$ $\mathrm{NH}_{4} \mathrm{NO}_{3}, 1 \mathrm{~g} / \mathrm{L} \mathrm{NaCl}, 0.25 \mathrm{~g} / \mathrm{L}$ anhydrous $\mathrm{MgSO}_{4}, 0.13 \mathrm{~g} / \mathrm{L} \mathrm{CaCl} 2.2 \mathrm{H}_{2} \mathrm{O}, 1 \mathrm{~g} / \mathrm{L}$ yeast extract, $12 \mathrm{~g} / \mathrm{L} \mathrm{PD,}$ $1 \mathrm{~g} / \mathrm{L}$ peptone, $1 \mathrm{~g} / \mathrm{L}$ acid hydrolysate of casein, $4 \mathrm{~g} / \mathrm{L}$ agarose) containing $100 \mu \mathrm{L}$ of the protoplast/PEG mixture evenly across $0.6 \%$ RG II plates containing $100 \mu \mathrm{g} / \mathrm{mL}$ hygromycin B.

\subsection{Fluorescence Microscopy}

Putative GFP- and DsRed-expressing endophyte transformants were examined using a Leica MZ FLIII fluorescence microscope (Leica Microsystems, Wetzlar, Germany) fitted with filters GFP2 and GFP3 with excitation filters at 480/40 and 470/40 nm, respectively, and barrier filters at $510 \mathrm{~nm}$ LP (Long Pass) and 525/50 nm, DsRed filter 546/10 nm and emission filter $565 \mathrm{~nm}$ LP.

Transformant colonies were examined for GFP and DsRed expression under a confocal microscope. Hyphae suspended in a drop of water were observed using an Olympus FluoView FV10i confocal microscope (Olympus, Tokyo, Japan). Filters (green-narrow with excitation maximum $473 \mathrm{~nm}$, emission maximum 490-540 $\mathrm{nm}$ and TRITC with excitation maximum $552 \mathrm{~nm}$ and emission maximum $578 \mathrm{~nm}$ ) were used to monitor GFP and DsRed expression.

Samples of endophyte infected plants were observed using a Leica M205 FA fluorescence stereo microscope (Leica Microsystems, Wetzlar, Germany) fitted with filters GFP2 and GFP3 with same excitation and barrier filters as above.

\subsection{Seedling Inoculation of Transgenic Endophytes}

Endophyte-devoid $\left(\mathrm{E}^{-}\right)$perennial ryegrass cultivar Alto seeds were obtained from Barenbrug Agriseeds, Christchurch, New Zealand. PCR-verified, fluorescent protein-expressing representatives from each reporter gene-containing endophyte strain (NEA12-GFP1, NEA12-DsRed9, E1-GFP2, and E1-DsRed4) were used for inoculations. A total of 60-75 seedlings were inoculated with each individual transgenic endophyte strain and 210-230 seedlings were co-inoculated with NEA12-GFP1 + NEA12-DsRed9, E1-GFP2 + E1-DsRed4, and E1-GFP2 + NEA12-DsRed9. Maintenance of inoculated plants were performed as previously described in [35]. Inoculated seedlings were incubated in a growth room $\left(23^{\circ} \mathrm{C}, 80 \mu \mathrm{Mm}^{-2} \mathrm{~s}^{-1}, 8-16 \mathrm{~h}\right.$ photoperiod) for 7 days and then transferred to the glasshouse and planted in 42 -cell plant trays filled with potting mix.

\subsection{Screening for the Presence of Endophytes in Planta}

Three tiller samples $(<0.5 \mathrm{~cm})$ were harvested from the base of 6-month-old soil grown plants, followed by freeze-drying (Virtis Genesis, 25XL, Gardiner, NY, USA) for 48 h. DNA was extracted using the Qiagen MagAttract DNA Extraction kit (Qiagen, Hilden, Germany) as per manufacturer's instructions. Presence of the reporter genes were assessed by real time amplification 
(2x Roche FastStart SYBR Green Master Mix (Roche Ltd., Mannheim, Germany), $200 \mathrm{nM}$ primers ( $g f p$-F: $5^{\prime}$-GGTGAACTTCAAGATCCGCC-3', $g f p$-R: 5'-GAGGGTGTTCTGCTGGTAGT-3': DsRed-F: 5'-GCGTGATGAACTTCGAGGAC-3', DsRed-R: 5'-TTCACGCCGATGAACTTCAC-3'), $2 \mu \mathrm{L}$ DNA template $(5 \mathrm{ng} / \mu \mathrm{L})$, in a total volume of $10 \mu \mathrm{L})$ using the BIORAD CFX96 Touch ${ }^{\mathrm{TM}}$ Real-Time PCR detection system (Bio Rad Laboratories Inc., Hercules, CA, USA) $\left(95^{\circ} \mathrm{C} 10 \mathrm{~min},\left(95^{\circ} \mathrm{C} 30 \mathrm{~s}, 60^{\circ} \mathrm{C} 1\right.\right.$ min) $\times 40$, melt curve $60-95{ }^{\circ} \mathrm{C}\left(0.5^{\circ} \mathrm{C}\right.$ increments) for $\left.5 \mathrm{~min}\right)$. Three technical replications for each sample were included. Plasmid DNA carrying $g f p$ or DsRed reporter genes $(0.5 \mathrm{ng})$ acted as the positive controls. Data were analysed by Bio-Rad CFX Manager software v.3.0 (Bio Rad Laboratories Inc., Hercules, CA, USA) using automatic threshold calling.

\subsection{DNA Sequencing and Analysis of Transgene Integration Sites}

\subsubsection{Illumina Sequencing}

Genomic DNA was quantified using a Qubit Fluorometer (Thermo Fisher Scientific, Walthman, MA, USA) and library of E1-GFP2 was prepared using the Nextera ${ }^{\mathrm{TM}}$ DNA sample prep kit (Illumina, Inc. San Diego, CA, USA) in accordance with the manufacturer's protocol. The library was quantified using the KAPA library quantification kit (KAPA Biosystems, Wilmington, MA, USA), and the insert size was measured with an Agilent 2100 bioanalyser (Agilent Technologies, San Diego, CA, USA). Sequencing was performed using Illumina MiSeq technology (Illumina, Inc. San Diego, CA, USA) according to the manufacturer's protocol.

\subsubsection{MinION Nanopore Library Preparation and Sequencing}

Genomic DNA was extracted, libraries were prepared, and sequencing performed as described in [6]. DNA was extracted from snap frozen endophyte mycelia using a cetyltrimethylammonium bromide (CTAB)-based extraction method. Genomic libraries were prepared and sequenced using ligation sequence preparation kit (SQK-LSK109; Oxford Nanopore, Oxford, UK).

\subsubsection{Processing of Sequencing Reads}

All Miseq reads were filtered using a custom Python script. All MinIon reads were filtered and assembled as described in [6]. Sequence correction, trimming, assembly, polishing the scaffolded assembly using short-reads generated from Illumina Miseq sequencing platform was also performed as described in [6]. In brief, sequence correction, trimming, and assembly was performed using the long-read assembler Canu v.1.8 [38]. Scaffolded assembly was polished with genome assembly improvement and variant detection tool Pilon v. 1.23 [39] using Miseq reads.

Presence, copy number, length, start and stop coordinates, as well as orientation of $g f p, h p h, g p d \mathrm{P}$, $\operatorname{trpCP}$, and $\operatorname{trpCT}$ in the endophyte genome were initially identified through nucleotide BLAST (Basic Local Alignment Search Tool) (version 2.2.25) analysis [40], which led to the identification of the pattern of T-DNA integration. Subsequently, junction sequences were identified and nucleotide BLAST against the transformation vector was performed to study their origin. The DNA sequences immediately upstream and downstream of the integration were analysed to determine associated microhomology and the genomic position of T-DNA integration in the endophyte genome.

\section{Results}

\subsection{Construction of Binary Reporter Gene Vectors}

The Gateway ${ }^{\mathrm{TM}}-$ enabled destination vector (pEND0002) containing $h p h$ selectable marker cassette was used to permit insertion of reporter genes between constitutive control elements. The expression-specific construct plasmids (pEND-DsRed, pEND-egfp, and pEND-sgfp) were constructed by replacement of the Gateway RFA-A cassette in vector pEND0002 by the reporter genes DsRed, egfp, and $s g f p$. 


\subsection{A. tumefaciens-Mediated Transformation of Endophyte Mycelia}

All binary vectors generated (pEND-DsRed, pEND-egfp, and pEND-sgfp) were transformed into $A$. tumefaciens cells of strains AGL1 and LBA 4404, and PCR analysis was used to confirm the presence of the transformed plasmids. Hygromycin B at $200 \mu \mathrm{g} / \mathrm{mL}$ was used for selection of putative transformants. Following co-cultivation with finely cut mycelium of NEA12 and E1, hygromycin B-resistant colonies developed 2-4 weeks after transformation. No growth was observed in the non-transgenic endophyte controls at this concentration of hygromycin.

Both $A$. tumefaciens strains produced hygromycin B-resistant transformants, but the number produced by AGL1 was five-times higher than for LBA 4404. Fifty-six transformants were obtained for NEA12. The number of individual putative E1 transformants was too large to be counted, due to high-density growth. Stable transformation events were confirmed by the ability of these putative transformants to grow effectively at high concentrations of hygromycin B $(300 \mu \mathrm{g} / \mathrm{mL})$.

\subsection{PCR Analysis and Mitotic Stability Assessment of Reporter Gene-Containing Endophytes}

A sub-set of randomly selected hygromycin B-resistant transformants from each endophyte strain (six SGFP, six EGFP, and six DsRed transformants) were analysed by PCR using primers specific for the $g f p$, DsRed, and hph genes. GFP and DsRed transformants, which produced the expected product sizes for $h p h$ (414 bp), gfp (440 bp), and DsRed (385 bp) genes, were identified.

A. tumefaciens-mediated transformation of coenocytic mycelia may result in mixtures of genetically distinct nuclei, both lacking and containing the integrated reporter gene. To minimise potential problems associated with chimeric expression of fluorescent proteins, protoplasts of PCR-positive reporter gene-containing endophytes were prepared and regenerated. One variant of GFP, SGFP, for each endophyte strain was used for further analysis. A total of 48 hygromycin B-resistant reporter gene-containing endophytes (12 from each of the reporter gene-containing endophyte strains NEA12:SGFP, NEA12:DsRed, E1:SGFP, and E1:DsRed) were analysed by PCR using primers specific to the $g f p, D s R e d$, and $h p h$ genes. The expected PCR product sizes were observed for all transformants (Figure S1).

Hygromycin B-resistant transformants expressing either the GFP or DsRed fluorescent proteins were sub-cultured for a minimum of five cycles over a period of six months. All tested transformants maintained the ability to grow on selection. After 12 months of consecutive sub-culture, reporter gene-containing endophytes for both target strains continued to express the respective fluorescent proteins.

\subsection{Visualisation of Reporter Gene Expression}

DsRed- and SGFP-specific fluorescence were observed for all transformants (Figure 1). Young, actively growing hyphae showed strong expression of GFP or DsRed, while longer-established mycelium exhibited reduced or negligible expression.

\subsection{In Planta Detection of Endophytes}

Representatives of each reporter gene-containing endophyte strain were assessed for the ability to efficiently inoculate perennial ryegrass seedlings using an RT-PCR assay that targets $g f p$ and DsRed. Initially, melt curve analysis was performed to confirm the specificity of primer annealing. Single sharp peaks were obtained, confirming primer specificity. Positive associations between ryegrass seedlings and reporter gene-containing endophytes were identified for NEA12-GFP1, NEA12-DsRed9, E1-GFP2, and E1-DsRed4. Infection frequencies obtained six months post inoculation are summarised in Table 2. 

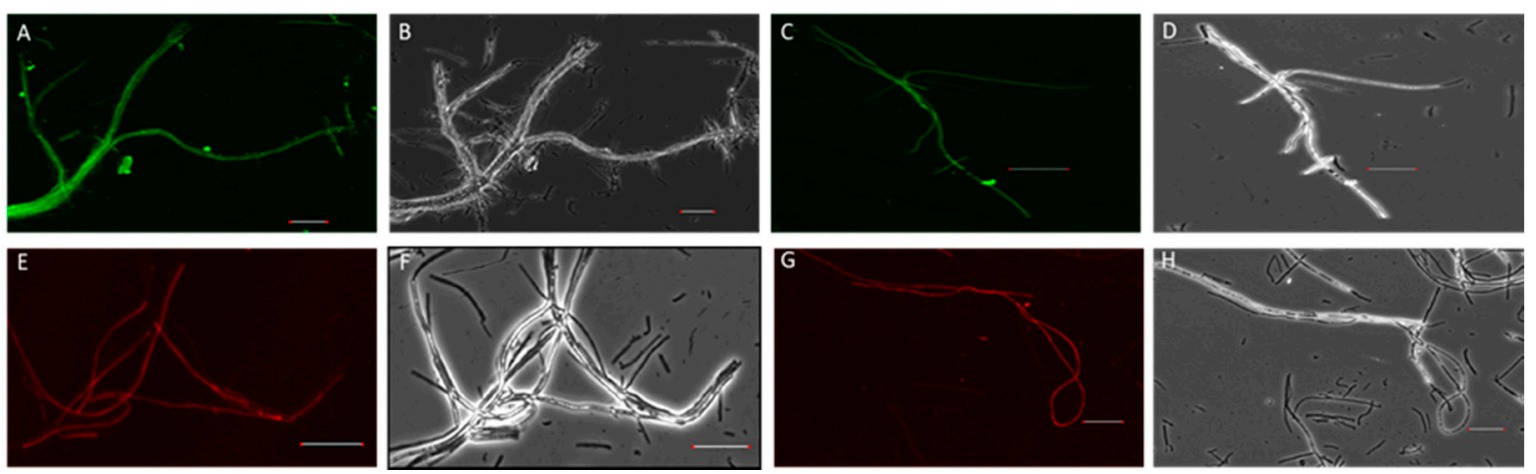

Figure 1. Confocal microscopy images of transgenic reporter mycelia (NEA12 and E1) expressing $s g f p$ and DsRed genes. (A) NEA12 mycelia expressing SGFP. (C) E1 mycelia expressing SGFP. (E) NEA12 mycelia expressing DsRed. (G) E1 mycelia expressing DsRed. (B), (D), (F), and (H) are bright field images of (A), (C), (E), and (G), respectively. Scale bar $=40 \mu \mathrm{m}$.

Table 2. Infection frequencies obtained for different reporter gene-containing endophyte strains.

\begin{tabular}{ccccc}
\hline Endophyte Strain & NEA12-GFP1 & E1-GFP2 & NEA12-DsRed9 & E1-DsRed4 \\
\hline Number of plants analysed & 60 & 60 & 49 & 57 \\
Infection frequency (\%) & 6.3 & 14.5 & 1.6 & 11.6 \\
\hline
\end{tabular}

Endophyte-infected plants that tested positive for the gfp and DsRed transgene using RT-PCR analysis were further analysed for fluorescence in planta. GFP- and DsRed-specific fluorescences were detected, more specifically, in the basal meristem and intercellular spaces of leaf sheaths of plants infected with reporter gene-containing endophytes (Figure 2).
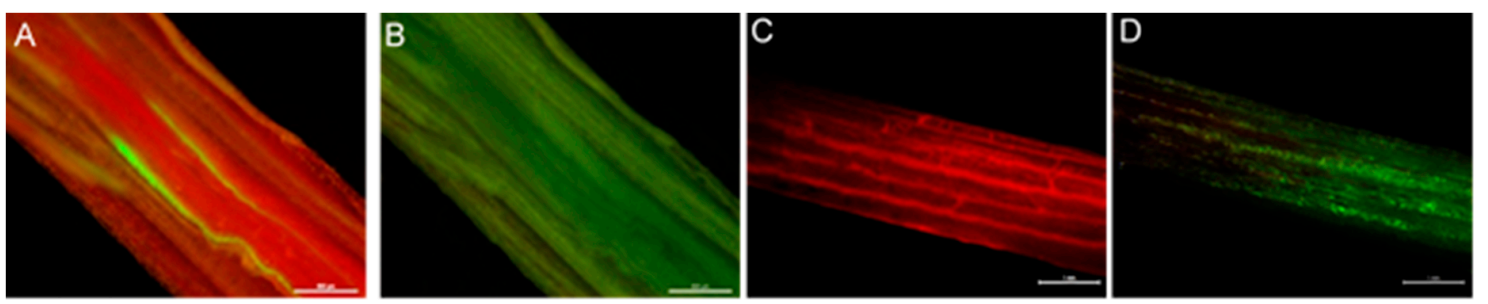

Figure 2. Fluorescence images of plant tissues inoculated with endophyte strain E1. (A) Expression of GFP at the base of a tiller. (C) Expression of DsRed in intercellular spaces of leaf sheath. (B,D) Corresponding bright-field images. Scale bar $=500 \mu \mathrm{M}$.

Secondly, to study the colonisation ability of endophytes of the same taxon or different taxa simultaneously in the same host, inoculation of complementary endophytes expressing GFP and DsRed was performed. Co-existence of GFP and DsRed expressing endophyte strains of the same taxon was identified, however GFP and DsRed expressing endophyte strains from different taxa were not observed to co-exist six months post inoculation (Table 3).

Table 3. Infection frequencies obtained for co-inoculated endophyte strains.

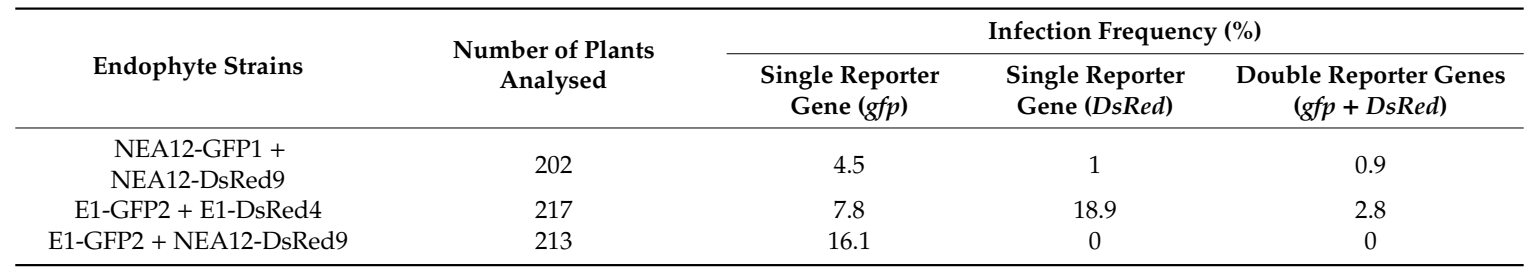




\subsection{DNA Sequencing and Analysis of Transgene Integration Sites}

Endophyte strain E1 was chosen for further studies due to the beneficial properties of this endophyte strain, such as a relatively fast growth rate and high inoculation ability compared to other asexual Epichloë strains. One representative of E1-GFP was sequenced using Illumina MiSeq and Oxford Nanopore MinION sequencing for detailed analysis of T-DNA integration in the endophyte genome. The Illumina MiSeq run generated 2,033,256 reads and the Oxford Nanopore MinION run produced 466,415 reads for a total of $5.3 \mathrm{Gbp}$ of data.

BLASTN analysis, as described above, was used to identify the presence of the transgenes and their corresponding promoters and terminators, and consequently the T-DNA integration site in the E1 genome. Integration of multiple T-DNA into a single locus close to the telomere in the 6,412,111 bp contig 3 of E1-GFP was detected (Figure 3A), resulting in a 35,530 bp insertion from 116,456 bp to 151,986 bp (Figure 3B).

Co-integration of multiple T-DNA copies (10 T-DNA insertions) including four reporter gene cassettes and eight selectable marker cassettes with some degradations and rearrangements were identified (Figure 3C). With one exception, all T-DNA copies were organised in the same orientation as the T-DNA region of the transformation vector (Figure 3D). Full-length as well as truncated promoter, gene, and terminator sequences were observed. Interestingly, all $g f p$ and trpCP insertions were found to be intact. One copy of $h p h$, at the terminus of a T-DNA insertion, was truncated, while the other seven $h p h$ genes were intact. The presence of both intact and truncated copies of $g p d \mathrm{P}$ and trpCT may be due to the fact that most of T-DNA-T-DNA junctions were between $g p d \mathrm{P}$ and $t r p C T$.

Three T-DNA copies (before junction 1, between junctions 1-2 and 8-9) contained $h p h$ and $g f p$ gene cassettes including their corresponding promoters and terminators without internal T-DNA sequence deletions. However, their terminators were truncated, especially the first terminator at the start of integration. Breaks in the middle of T-DNA copies were identified for all other T-DNA copies, indicating some form of partial deletion during T-DNA integration.

T-DNA integration in the recipient E1 genome did not occur at the LB and RB sequences. For example, integration of one terminus occurred at $t r p C T$ and the other end at the $h p h$ gene. Short stretches of both trpCT and hph components were identified at these termini of integration; $10 \mathrm{bp}$ compared to $775 \mathrm{bp}$ long intact trpCT and $226 \mathrm{bp}$ compared to intact $1020 \mathrm{bp}$ long hph. Comparison between T-DNA end sequences and genome sequences at insertion sites revealed that T-DNA integration was associated with 3 bp microhomology between genomic DNA and one T-DNA terminus. Exact union between the T-DNA border and genomic DNA was observed at the other terminus.

Nine T-DNA-T-DNA junctions were observed at the single integration locus identified in the E1-GFP genome. The T-DNA-T-DNA junctions identified included two LB-RB junctions (1 and 4), four trpCT-truncated $g p d \mathrm{P}$ junctions $(5,6,7$, and 8), one between two truncated trpCT (2), one gpdP-truncated $\operatorname{trpCT}(3)$ junction, and one trpCT-truncated $h p h$ junction (9). No precise junction involving an intact left and right border was found. Furthermore, no vector backbone insertions or filler sequences were identified.

Junctions 1,2, and 4 are between two trpCT. Analysis of these junctions identified that junction sequences consist of the three last bp of the LB to the start of trpCT of the $h p h$ cassette and first three bp of the RB, except junction 2 where the sequence between the LB and the start of trpCT of the $h p h$ cassette is missing. All three RBs identified (1,2, and 4) displayed a breakpoint located three bases (TGA) into the border sequence. Between junctions 4 and 8 , four replicates of the left part of the T-DNA region (trpCT-hph-trpCP-gpdP) were identified.

Junctions 5, 6, 7, and 8 were very similar and are between an intact trpCT and a $g p d \mathrm{P}$ with a $280 \mathrm{bp}$ truncation, except at junction 2 where the $\operatorname{trpCT}$ terminator has a $239 \mathrm{bp}$ truncation. These junction sequences were matched $100 \%$ to the vector sequence between $\operatorname{trpCT}$ and two (7 and 8 ) or three (5 and 6) bp before the start of the RB. The components of the $g f p$ gene cassette, which are located after $g p d P$ ( $g f p$ and $\operatorname{trpCT}$ ), have been truncated at some stage of T-DNA integration and linked to trpCT of the $h p h$ gene cassette (the sequence from the LB to the start of trpCT is also truncated). Junctions 9 (between an intact trpCT and $h p h(226 \mathrm{bp}))$ and 3 (trpCT (320 bp) and gpdP (336 bp)) are unique. 
A $\stackrel{\circ}{\circ}$
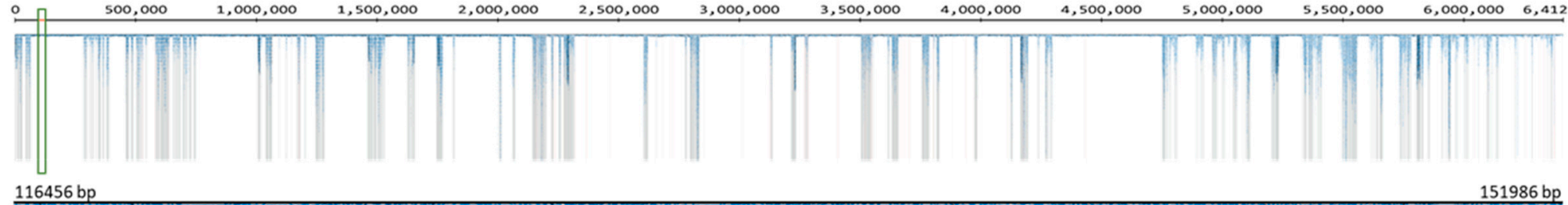

$51986 b$

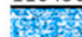

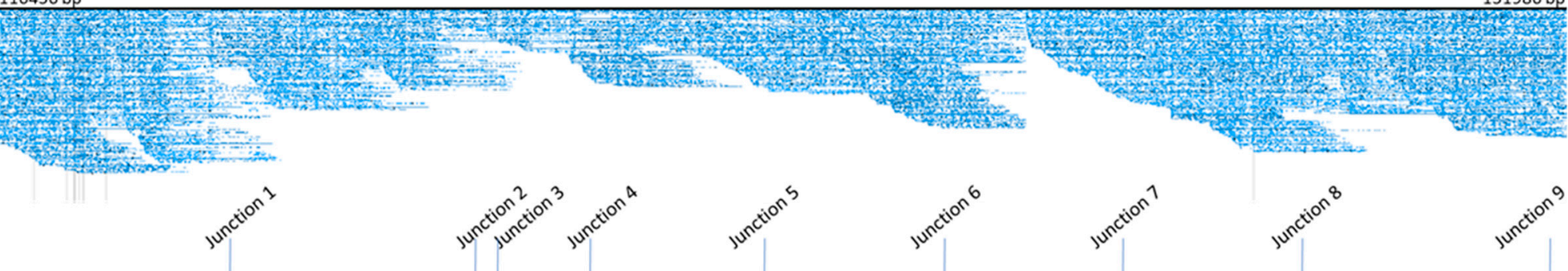

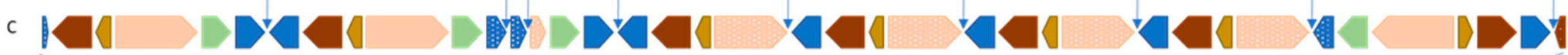
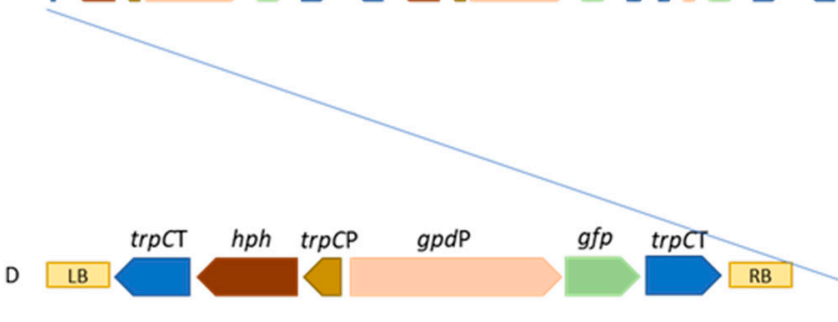

E

Gene $C$

Gene $D$

Gene $E$

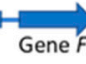

Gene $G$

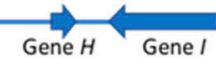

F CCGCCTCGAAAATGACTTGTCCGACGGGAGTGTCACCGTTCGTTIGACGACCGACGACCGCTCGATCGCTTCTGCTGCGTCCGTGGCCTTCTCAAGCTCGAGTCTCGCGTAGGAACTGGCTGAGAAATTCCGTACATGGTCTTITCC

Figure 3. (A) Gydle output showing MinIon reads mapped to contig $3(6,412,111 \mathrm{bp}$ ) of E1-GFP (integration site is highlighted in green box). (B) Gydle output showing MinIon reads mapped to the integration site. (C) Schematic representation showing the pattern of T-DNA integration in the E1 genome. Arrows indicate the junctions between T-DNAs and dotted blocks indicate truncations of more than $15 \mathrm{bp}$. (D) Schematic representation of the T-DNA region of the transformation vector, pEND-sgfp, showing relative position of the selectable marker $(h p h)$, promoter sequences $(g p d \mathrm{P}, \operatorname{trp} C \mathrm{P})$, reporter gene $(g f p)$, terminator sequences $(\operatorname{trp} C \mathrm{~T})$, left border (LB), and right border (RB). (E) Schematic representation of the genes upstream and downstream of the integration site. (F) The 10 bp deletion in the E1 genome associated with the T-DNA event (deletion is highlighted in green). 
T-DNA integration was identified at contig 3, which started with 17 copies of a telomeric repeat (TAACCC). The T-DNA has integrated into a gene-rich region of the E1 genome; analysis of T-DNA-genome junction sequences identified that T-DNA is integrated into a gene predicted to encode for a hydrolase (Pochonia chlamydosporia 170 hydrolase, $\alpha / \beta$ fold family protein (XM_018288623.1)) (Gene $E$ ) (Figure 3E). Further study of the genes immediately upstream and downstream of Gene $E$ indicates that these genes are highly conserved, with closely related Clavicipitacae species such as Metarhizium brunneum, M. acridumm and P. chlamydosporia (Table S2). This insertion event is associated with a 10 bp deletion in Gene $E$ of the E1 genome (Figure 3F).

\section{Discussion}

\subsection{Vector Construction and A. tumefaciens-Mediated Transformation}

GFP variants such as SGFP and EGFP have been shown to confer high levels of fluorescence in several fungal species, including Cochliobolous heterostrophus, Ustilago maydis, F. oxysporum, and Phytophthora palmivora [41-44]. Similarly, the codon-optimised version of DsRed has been expressed successfully in filamentous fungi such as Verticillium albo-atrum, F. oxysporum, L. maculans, L. biglobosa, Oculimacula yallundae, O. acuformis, Penicillium paxilli, and Trichoderma harzianum [13,45-48]. Constitutive and heritable expression of GFP fluorescence in transgenic organisms has provided an ideal system for assessment of organismal viability [49]. In addition, major advantages of the use of reporter genes to study the host-endophyte association include the ability to visually locate fungal mycelia in planta; hence, ideal for monitoring different stages of life cycle, provide fast real-time temporal resolution, facilitate rapid screening and discrimination of different inoculated strains, as well as to distinguish inoculated strains from naturally present plant-associated microorganisms [10,18,50]. Based on all these desirable qualities of fluorescent proteins, $s g f p$, egfp, and DsRed were selected as reporter genes for the present study.

Expression vectors containing the reporter genes were constructed using Gateway ${ }^{\mathrm{TM}}$ cloning and transformed using two A. tumefaciens strains, AGL1 and LBA 4404. Ability to induce tumours on particular plant species, which are the natural primary host, varies between $A$. tumefaciens strains, and it is unclear whether similar variation arises in respect to the capacity to also transform fungi [51]. In the present study, the transformation efficiency of the AGL1 and LBA 4404 strains differed substantially. AGL1 has previously been shown to be more efficient than other $A$. tumefaciens strains for transformation of both ascomycete and basidiomycete fungal species [52,53], consistent with the outcomes of this study. A further practical limitation of the use of LBA 4404 is a tendency to form aggregates in liquid culture, which makes accurate determination of optical density difficult [46].

The backbone vector used in this study was conveniently manipulated for multiple other purposes, in addition to the successful expression of GFP and DsRed. This included modification of the vector to express peramine in culture and in planta [35], as well as for construction of gene silencing vectors to identify the genes responsible for epoxy-janthitrem biosynthesis [6].

\subsection{Molecular Analysis of Transformants}

PCR-based analysis confirmed presence of $h p h$ and the corresponding reporter gene in transformants that were identified based on growth on antibiotic selection media following $A$. tumefaciens-mediated transformation.

\subsection{Expression of Fluorescence Proteins in Culture}

Visualisation of GFP and DsRed expression in reporter gene-containing endophytes showed that the level of fluorescence varied between individual transformants, potentially reflecting copy number and position effects. However, microscope-based examination revealed no gross differences in expression levels between the two GFP variants, sgfp (codon-optimised for higher plants [54]) or egfp (codon-optimised for mammals [54]). Growing hyphal tips always exhibited higher expression 
of GFP or DsRed presumably due to relatively high nuclear density. This observation may also be due to variable levels of transgene expression in some nuclei according to developmental stage or transgene silencing in non-dividing mycelial cells. In common with the present study, physical variation in the intensity of florescent protein expression has been observed for Botrytis cinerea, Pyrenophora tritici-repentis, and Sclerotinia sclerotiorum $[42,55]$.

Expression of GFP and DsRed was stable in transformants of both endophyte strains and did not disappear after subsequent sub-culture over a period of twelve months. High rates of mitotic stability of gfp gene containing transformants of different fungal species generated by A. tumefaciens-mediated transformation have also been reported in other studies [56,57].

A. tumefaciens-mediated transformation of mycelia may result in cells that have genetically different nuclei, some containing and some lacking the integrated reporter gene. Therefore, protoplasts from PCR-positive transformants were prepared to mitigate the risk of analysing mycelia with chimeric nuclear content arising from both transformed and non-transformed nuclei. This strategy is vulnerable to the possibility that protoplasts may be multinucleate rather than uninucleate, which could inadvertently capture both transformed and non-transformed nuclei. However, sequence analysis confirmed the presence of single transformed nuclei in E1-GFP transformant. Purification of transformants has also been attempted by subculturing of hyphal tips and serial transfers on selective media [42]. However, homokaryotic mutants of Monilinia fructicola were not identified even after four rounds of single hyphal tip purification [58].

\subsection{Inoculation Ability of Reporter Gene-Containing Endophyte Strains and in Planta Fluorescent Protein Expression}

Fluorescent proteins provide a unique and visual phenotype for studying plant-microbe interactions without any external intervention, and so providing valuable information on in planta development of endophyte. The colonisation ability of a transgenic endophyte could be compromised by transgene insertion, especially if a critical gene is disrupted [59]. Therefore, one representative from each reporter gene-containing endophyte strain was assessed for their infection ability. Colonisation ability was observed for $g f p$ and DsRed containing NEA12 and E1 endophyte strains six months after inoculation indicating vegetative stability of the host-endophyte association over time.

GFP- and DsRed-specific fluorescence of plants infected with transgenic endophytes was observed in basal meristems, as well as in intercellular spaces in which endophytes are abundantly located. Each individual plant infected with a transgenic endophyte strain showed normal growth in the glasshouse and stable expression of either GFP or DsRed was retained. The stability of the associations established provides evidence for the ultimate value of reporter gene-expressing endophytes for assessment of spatial and temporal changes during host colonisation and longer-term evaluation of symbiota through a time-course of plant growth and development to the next generation through the seeds, while emphasising the importance of access to endophyte strains of different taxa with different fluorescent protein expressions.

\subsection{Co-Existence Ability of Reporter Gene-Containing Endophyte Strains}

This study used endophyte strains that belong to same and different taxa which express GFP and DsRed to investigate co-existence potential of endophytes within the same host plant. Only a few studies have so far attempted to understand this phenomenon, and the mechanisms that govern an inability to co-exist within the same tiller are yet to be elucidated [60-62]. As part of the studies performed so far, different endophyte strains in the same host have been distinguished based on characteristics such as presence or absence of conidia, production of certain specific alkaloids, and RAPD (random amplification of polymorphic DNA) profiles [60,61]. However, none of these identification methods can provide real-time temporal resolution, as may be achieved by use of fluorescent proteins. No prior study of co-existence and distribution of multiple endophytes within an individual plant have used fluorescent-labelled endophytes, so the strains described here provide dynamic tools for a 
better understanding of the mechanisms involved during co-inoculation, co-existence, and competition between co-inoculated strains.

Co-inoculation events were identified for both NEA12-GFP1 + NEA12-DsRed9 and E1-GFP2 + E1-DsRed4 suggesting stable co-colonisation is possible within the same taxa. Only E1-GFP was identified for plants inoculated with both E1-GFP2 + NEA12-DsRed9. E1 has a faster growth rate and high inoculation ability compared to NEA12. These attributes may have enabled E1 to outcompete and become dominant. This characteristic of E1 has also been observed in other co-inoculation studies using different perennial ryegrass endophyte strains. This co-inoculation study was performed mainly to understand the potential of using these reporter gene-containing endophyte strains to study host-endophyte interactions. However, it would be beneficial to co-inoculate and analyse a greater number of plants to understand the co-infection ability of endophytes precisely. It has been found that hyphae of the dominant strain colonised primordial tillers arising from a dually infected plants, and co-existence disappeared over time, giving rise to plants in which all tillers contained a single strain [60].

\subsection{Bioinformatic Analysis of Transgene Integration Sites}

T-DNA integration is a complex process and its mechanism is not yet completely understood [32,63]. Understanding the complex nature of T-DNA integrations may help to develop and optimise transformation methods and conditions to achieve transformants with only intended modifications. Integration patterns of T-DNA in a small number of plant genomes have been studied in detail [31,64]. In the case of fungi, even though A. tumefaciens-mediated transformation has been used extensively for generation of transgenic strains, integration patterns of T-DNA in fungal genomes has not been characterised to the same extent [65-67]. A detailed understanding of T-DNA integration is essential to develop transformation methods to obtain a more desirable outcome, which is very important for both commercial and research purposes [25,32]. Traditionally, molecular techniques such as Southern blotting, PCR, and genome walking have been used for characterisation of T-DNA integration $[21,57,68]$. However, these approaches are not capable of identifying complex integration events [69]. Next-generation sequencing has been used more effectively for the analysis of T-DNA integration patterns. Although there are limitations such as difficulties in assembling large repeat structures and other complex regions accurately [64]. Further, due to the short reads generated, these sequencing methods only identify flanking sequences of T-DNA and genomic DNA [64]. More recently, the combination of next-generation sequencing and third-generation techniques such as PacBio and MinIon sequencing have been used to analyse T-DNA integration events and associated genomic variations in the recipient genome with higher precision and in greater detail [31,64]. However, to date, studies using long read sequencing to analyse T-DNA integration events are limited to a few plant species such as Arabidopsis and Betula (birch) [31,64].

This study used a combination of second- and third-generation sequencing (Miseq and MinIon, respectively) to identify and characterise T-DNA integration in the endophyte strain, E1-GFP. Insertion of $35 \mathrm{~kb}$ containing 10 T-DNA copies was identified in contig 3 of E1-GFP, which is homologous to chromosome III of E. festucae strain Fl1, $6 \mathrm{Mb}[70,71]$. For some fungi, the number of T-DNA copies integrated may depend on the A. tumefaciens-based transformation method. In A. aculeatus, Blastomyces dermatitidis, and Suillus bovinus, a high concentration of A. tumefaciens cells resulted in multiple copy integrations, while low concentrations resulted predominantly in single copy integrations [72]. However, A. tumefaciens concentration exerted no obvious influence on T-DNA copy number in $F$. oxysporum [73]. Occurrence of transformants with single or multiple copy T-DNA integration patterns has also been shown to depend on the addition of acetosyringone to the A. tumefaciens pre-culture and the length of the co-cultivation period [22,74]. Presence of multiple T-DNA inserts in the E1-GFP strain analysed could potentially be due to the nature of the transformation conditions used in this study. These conditions included a co-cultivation time of $72 \mathrm{~h}$ and pre-treatment of the A.tumefaciens 
cells with acetosyringone prior to co-cultivation with endophyte mycelia. T-DNA may have been sequentially integrated into a single recipient genome through more than one round of transformation.

T-DNA truncations at both the LB and RB as well as deletions of borders were observed in the present study. Three right-border breakpoints (with only the first $3 \mathrm{bp}$ of RB) were detected in three of the nine junctions while two left-border breakpoints (with only the last $3 \mathrm{bp}$ ) were detected in two of nine junctions identified. Consistent with this observation, the most commonly identified right-border breakpoint is at the first three nucleotides (TGA) of the RB sequence [24]. This is consistent with the expected nick point between the third and fourth nucleotide of the $25 \mathrm{bp}$ repeat [24]. Truncations of T-DNA may arise either due to recognition of non-border as border sequences, with subsequent nicking of the T-DNA at these locations, or to exonuclease digestion of the T-DNA ends prior to integration or breakage of the T-DNA during transfer [24]. In M. oryzae, the LB sequence is truncated at a high frequency when compared to the RB [20,75]. In contrast, conservation of both borders has been observed for transformants of L. maculans [67].

Four $g f p$ cassettes were present in ten T-DNA copies identified. Three of them contained intact $g f p$ genes and intact $g p d \mathrm{P}$ promoters. Only one of those three cassettes have full length $\operatorname{tr} p \mathrm{CT}$ while the other two have truncated $\operatorname{trpCT}(<250 \mathrm{bp}$ truncations). The fourth $g f p$ gene cassette has a full-length $g f p$ gene with very short fragments of corresponding promoter and terminator and therefore may not be transcribed. The other six T-DNA copies contained $h p h$ cassettes with truncated gpdP. Deletions of T-DNA were observed not only at the ends, but also in the middle of the T-DNA. Interestingly, four replicates of the left part of the T-DNA ( $\operatorname{tr} p \mathrm{CT}-h p h-t r p C \mathrm{P}-g p d \mathrm{P})$ were observed between junctions 4 and 8 proving the complex nature of T-DNA integration. This could be due to occasional random nicking of the T-DNA and nuclease digestion of the T-DNA ends [24]. The integration of DNA with part of the T-DNA fragment missing or with rearrangements has been identified frequently in plant genomes [64]. This complex pattern of T-DNA integration was further confirmed by long read sequences that span the entire $35 \mathrm{~kb}$ integration.

Integration of T-DNA requires a DNA repair pathway. In fungi, the main pathway is non-homologous end-joining (NHEJ), however targeted integration of the T-DNA by homologous recombination $(\mathrm{HR})$ is also possible in species such as yeast [76,77]. NHEJ requires a small microhomology of up to $5 \mathrm{bp}$ between T-DNA and host genomic DNA whereas homologous recombination requires extensive DNA sequence homology [76-78]. During NHEJ, some rearrangements such as deletions of a few nucleotides and/or duplications have been observed at double strand break sites in plants [77]. In this study, microhomology of $3 \mathrm{bp}$ was observed at the junction between one T-DNA terminus and endophyte genome, suggesting that T-DNA integration in Epichloë does not depend upon long stretches of homology at cross-over points, similarly to that observed for M. oryzae [75]. No microhomology of T-DNA end and genome was observed at the other end of the integration. Microhomology between T-DNA ends and the genomic DNA has also been reported for other fungi such as $S$. cerevisiae and C. neoformans [20,27]. Identification of a 10 bp deletion of endophyte genome sequence around the insertion site in this study is consistent with observations for other fungi including M. oryzae and C. neoformans. Similar to the results of the current study, most of the identified deletions were less than $20 \mathrm{bp}$ in length in these fungi $[20,75]$.

Analysis of genomic flanking sequences in the present study identified that the T-DNA has integrated in a gene-rich region of E1 genome and more specifically into a gene predicted to coding for a hydrolase. Still, it is debatable whether T-DNA integration targets certain genomic regions or it happens in a completely random manner [79]. Greater susceptibility of regions upstream from genes, as well as intergenic regions, to T-DNA integrations has been reported in the pathogenic fungus $H$. capsulatum [21]. In contrast, relatively even distribution of T-DNA integration events throughout the genome was observed for S. cerevisiae, L. maculans, and M. grisea [28].

This study revealed the complex nature of T-DNA integrations in fungi through analysis of a single transformant. Multiple T-DNA insertions with truncations of different lengths were identified with precise detail using a combination of long read and short read sequence data. These outcomes 
show the need for more thorough study of T-DNA integration in fungal genomes to better understand the process of T-DNA integration. This study has implications for genome modification, including genome editing, of fungal genomes using A. tumefaciens-mediated transformation and can further be explored to understand other structural variations of fungal genomes, which can be caused by T-DNA insertions.

\section{Conclusions}

A new set of fluorescent protein expression vectors were generated to study biological processes in endophytic filamentous fungi. Derivatives of endophyte strains NEA12 and E1 that express GFP and DsRed were generated and characterised in detail using a range of analytical techniques. Stable integration and expression of transgenes in endophytic fungi provides an efficient tool for exploration of the ability of endophytes to colonise plant tissue, to establish new inoculation methods and for the study of numerous aspects of host-endophyte and endophyte-endophyte interactions. A more detailed understanding of the mechanisms controlling endophyte co-existence will permit establishment of artificial symbioses between endophytes and host grasses that are capable of providing a larger range of benefits to host plants, through combinations of beneficial properties such as production of complementary bioprotective alkaloids for pest and disease control. Sequence analysis of T-DNA integration emphasizes the importance of development and optimisation of transformation protocols as well as screening the transformants in detail, most importantly in technologies such as foreign-DNA free genome editing. This is the first study to use a combination of second- and third-generation DNA sequencing methods to analyse copy number, sites, and exact structures of T-DNA integration events in fungal genomes with precise detail.

Supplementary Materials: The following are available online at http://www.mdpi.com/2076-2607/8/1/54/s1.

Author Contributions: Conceptualization, I.K.H., K.M.G., T.I.S., and G.C.S.; methodology, I.K.H., P.N.E., E.J.L., N.D.B., and S.S.; manuscript writing, editing, and review, I.K.H., K.M.G., and E.J.L., supervision and project administration, K.M.G. and G.C.S. All authors approved the final manuscript. All authors have read and agreed to the published version of the manuscript.

Funding: The research described here was funded by Agriculture Victoria and Dairy Australia.

Acknowledgments: We are grateful to John Forster for his contribution.

Conflicts of Interest: The authors declare no conflict of interest.

\section{References}

1. Leuchtmann, A.; Schmidt, D.; Bush, L.P. Different levels of protective alkaloids in grasses with stroma-forming and seed-transmitted Epichloë/Neotyphodium endophytes. J. Chem. Ecol. 2000, 26, 1025-1036. [CrossRef]

2. Leuchtmann, A.; Bacon, C.W.; Schardl, C.L.; White, J.J.F.; Tadych, M. Nomenclatural realignment of Neotyphodium species with genus Epichloë. Mycologia 2014, 106, 202-215. [CrossRef] [PubMed]

3. Clay, K.; Schardl, S. Evolutionary origins and ecological consequences of endophyte symbiosis with grasses. Am. Nat. 2002, 160, S99-S127. [CrossRef] [PubMed]

4. Schardl, C.; Grossman, R.; Nagabhyru, P.; Faulkner, J.; Mallik, U. Loline alkaloids: Currencies of mutualism. Phytochemistry 2007, 68, 980-996. [CrossRef] [PubMed]

5. Bush, L.P.; Wilkinson, H.H.; Schardl, C.L. Bioprotective alkaloids of grass-fungal endphyte sysmbioses. Plant Physiol. 1997, 114, 1-7. [CrossRef] [PubMed]

6. Ludlow, E.; Vassiliadis, S.; Ekanayake, P.N.; Hettiarachchige, I.K.; Reddy, P.; Sawbridge, T.I.; Rochfort, S.J.; Spangenberg, G.C.; Guthridge, K.M. Analysis of the indole diterpene gene cluster for biosynthesis of the epoxy-janthitrems in Epichloë endophytes. Microorganisms 2019, 7, 560. [CrossRef]

7. Christensen, M.J.; Leuchtmann, A.; Rowan, D.D.; Tapper, B.A. Taxonomy of Acremonium endophytes of tall fescue (Festuca arundinacea), meadow fescue (F. pratensis) and perennial ryegrass (Lolium perenne). Mycol. Res. 1993, 97, 1083-1092. [CrossRef] 
8. Hettiarachchige, I.K.; Ekanayake, P.N.; Mann, R.C.; Guthridge, K.M.; Sawbridge, T.I.; Spangenberg, G.C.; Forster, J.W. Phylogenomics of asexual Epichloë fungal endophytes forming associations with perennial ryegrass. BMC Evol. Biol. 2015, 15, 72. [CrossRef]

9. Reddy, P.V.; Lam, C.K.; Belanger, F.C. Mutualistic fungal endophytes express a proteinase that is homologous to proteases suspected to be important in fungal pathogenicity. Plant. Physiol. 1996, 111, 1209-1218. [CrossRef]

10. Ezra, D.; Skovorodnikova, J.; Kroitor-Keren, T.; Denisov, Y.; Liarzi, O. Development of methods for detection and Agrobacterium-mediated transformation of the sterile, endophytic fungus Muscodor albus. Biocontrol Sci. Technol. 2009, 20, 83-97. [CrossRef]

11. Lippincott-Schwartz, J.; Patterson, G.H. Development and use of fluorescent protein markers in living cells. Science 2003, 300, 87-91. [CrossRef] [PubMed]

12. Hruska, Z.; Rajasekaran, K.; Yao, H.; Kinkaid, R.; Darlington, D.; Brown, R.L.; Bhatnagar, D.; Cleveland, T.E. Co-inoculation of aflatoxigenic and non-aflatoxigenic strains of Aspergillus flavus to study fungal invasion, colonization, and competition in maize kernels. Front. Microbiol. 2014, 5, 1-7. [CrossRef] [PubMed]

13. Mikkelsen, L.; Sarrocco, S.; Lübeck, M.; Jensen, D.F. Expression of the red fluorescent protein DsRed-Express in filamentous Ascomycete fungi. FEMS Microbiol. Lett. 2003, 223, 135-139. [CrossRef]

14. Christensen, M.J.; Bennett, R.J.; Ansari, H.A.; Koga, H.; Johnson, R.D.; Bryan, G.T.; Simpson, W.R.; Koolaard, J.P.; Nickless, E.M.; Voisey, C.R. Epichloë endophytes grow by intercalary hyphal extension in elongating grass leaves. Fungal Genet. Biol. 2008, 45, 84-93. [CrossRef]

15. Mikkelsen, L.; Roulund, N.; Lübeck, M.; Jensen, D.F. The perennial ryegrass endophyte Neotyphodium lolii genetically transformed with the green fluorescent protein gene (GFP) and visualization in the host plant. Mycol. Res. 2001, 105, 644-650. [CrossRef]

16. Dombrowski, J.E.; Baldwin, J.C.; Alderman, S.C.; Martin, R.C. Transformation of Epichloë typhina by electroporation of conidia. BMC Res. Notes 2011, 4, 1-7. [CrossRef]

17. Nizam, S.; Singh, K.; Verma, P. Expression of the fluorescent proteins DsRed and EGFP to visualize early events of colonization of the chickpea blight fungus Ascochyta rabiei. Curr. Genet. 2010, 56, 391-399. [CrossRef]

18. Van West, P.; Reid, B.; Campbell, T.A.; Sandrock, R.W.; Fry, W.E.; Kamoun, S.; Gow, N.A.R. Green fluorescent protein (GFP) as a reporter gene for the plant pathogenic oomycete Phytophthora palmivora. FEMS Microbiol. Lett. 1999, 178, 71-80. [CrossRef]

19. Dos Reis, M.C.; Fungaro, M.H.P.; Duarte, R.T.D.; Furlaneto, L.; Furlaneto, M.C. Agrobacterium tumefaciens-mediated genetic transformation of the entomopathogenic fungus Beauveria bassiana. J. Microbiol. Methods 2004, 58, 197-202. [CrossRef]

20. Meng, Y.; Patel, G.; Heist, M.; Betts, M.; Tucher, S.; Galadima, N.; Donofrio, N.; Brown, D.; Mitchell, T.; Li, L.; et al. A systematic analysis of T-DNA insertion events in Magnaporthe oryzae. Fungal Genet. Biol. 2007, 44, 1050-1064. [CrossRef]

21. Kemski, M.M.; Stevens, B.; Rappleye, C.A. Spectrum of T-DNA integrations for insertional mutagenesis of Histoplasma capsulatum. Fungal Biol. 2013, 117, 41-51. [CrossRef] [PubMed]

22. Rho, H.S.; Kang, S.; Lee, H.Y. Agrobacterium tumefaciens mediated transformation of the plant pathogenic fungus Magnaporthe grisea. Mol. Cells 2001, 12, 407-411. [PubMed]

23. Sun, L.; Ge, Y.; Sparks, A.; Robinson, Z.; Cheng, X.; Wen, J.; Blancaflor, E. TDNAscan: A software to identify complete and truncated T-DNA insertions. Front. Genet. 2019, 10, 685. [CrossRef] [PubMed]

24. Bartlett, J.G.; Smedley, M.A.; Harwood, W.A. Analysis of T-DNA/host-plant DNA junction sequences in single-copy transgenic barley lines. Biology 2014, 3, 39-55. [CrossRef] [PubMed]

25. Wei, S.; Xi, Y.Z.; Song, D.P.; Wei, H.; Gruber, M.Y.; Gao, M.J.; Parkin, I.; Kachatourians, G.; Hannoufa, A. Quantitative and structural analyses of T-DNA tandem repeats in transgenic Arabidopsis SK mutant lines. Plant Cell Tissue Organ. Cult. (PCTOC) 2015, 123, 183-192. [CrossRef]

26. Michielse, C.B.; van Wijk, R.; Reijnen, L.; Cornelissen, B.J.; Rep, M. Insight into the molecular requirements for pathogenicity of Fusarium oxysporum $f$. sp. lycopersici through large-scale insertional mutagenesis. Genome Biol. 2009, 10, R4. [CrossRef]

27. Bundock, P.; van Attikum, H.; den Dulk-Ras, A.; Hooykaas, P.J.J. Insertional mutagenesis in yeasts using T-DNA from Agrobacterium tumefaciens. Yeast 2002, 19, 529-536. [CrossRef] 
28. Idnurm, A.; Walton, F.J.; Floyd, A.; Reedy, J.L.; Heitman, J. Identification of ENA1 as a virulence gene of the human pathogenic fungus Cryptococcus neoformans through signature-tagged insertional mutagenesis. Eukaryot Cell 2009, 8, 315-326. [CrossRef]

29. Zhang, R.; Yin, Y.; Zhang, Y.; Li, K.; Zhu, H.; Gong, Q.; Wang, J.; Hu, X.; Li, N. Molecular characterization of transgene integration by next-generation sequencing in transgenic cattle. PLOS ONE 2012, 7, e50348. [CrossRef]

30. Kovalic, D.; Garnaat, C.; Guo, L.; Yan, Y.; Groat, J.; Silvanovich, A.; Ralston, L.; Huang, M.; Tian, Q.; Christian, A.; et al. The use of next generation sequencing and junction sequence analysis bioinformatics to achieve molecular characterization of crops improved through modern biotechnology. Plant Genome 2012, 5 , 149-163. [CrossRef]

31. Jupe, F.; Rivkin, A.C.; Michael, T.P.; Zander, M.; Motley, S.T.; Sandoval, J.P.; Slotkin, R.K.; Chen, H.; Castanon, R.; Nery, J.R.; et al. The complex architecture and epigenomic impact of plant T-DNA insertions. PLoS Genet. 2019, 15, e1007819. [CrossRef] [PubMed]

32. Singer, K. The mechanism of T-DNA integration: Some major unresolved questions. In Agrobacterium Biology: From Basic Science to Biotechnology; Gelvin, S.B., Ed.; Springer International Publishing: Cham, Switzerland, 2018; pp. 287-317.

33. Gelvin, S.B. Integration of Agrobacterium T-DNA into the Plant Genome. Annu. Rev. Genet. 2017, 51, $195-217$. [CrossRef] [PubMed]

34. Kaur, J.; Ekanayake, P.; Tian, P.; van Zijll de Jong, E.; Dobrowolski, M.P.; Rochfort, S.J.; Mann, R.; Smith, K.F.; Forster, J.W.; Guthridge, K.M.; et al. Discovery and characterisation of novel asexual Epichloë endophytes from perennial ryegrass (Lolium perenne L.). Crop Pasture Sci. 2015, 66, 1058-1070. [CrossRef]

35. Hettiarachchige, I.K.; Elkins, A.C.; Reddy, P.; Mann, R.C.; Guthridge, K.M.; Sawbridge, T.I.; Forster, J.W.; Spangenberg, G.C. Genetic modification of asexual Epichloë endophytes with the perA gene for peramine biosynthesis. Mol. Genet. Genom. 2019, 294, 315-328. [CrossRef]

36. Hajdukiewicz, P.; Svab, Z.; Maliga, P. The small, versatile pPZP family of Agrobacterium binary vectors for plant transformation. Plant Mol. Biol. 1994, 25, 989-994. [CrossRef]

37. Moller, E.M.; Bahnweg, G.; Sandermann, H.; Geiger, H.H. A simple and efficient protocol for isolation of high molecular weight DNA from filamentous fungi, fruit bodies and infected plant tissue. Nucleic Acids Res. 1992, 20, 6115-6116. [CrossRef]

38. Koren, S.; Walenz, B.P.; Berlin, K.; Miller, J.R.; Bergman, N.H.; Phillippy, A.M. Canu: Scalable and accurate long-read assembly via adaptive k-mer weighting and repeat separation. Genome Res. 2017, 27, 722-736. [CrossRef]

39. Walker, B.J.; Abeel, T.; Shea, T.; Priest, M.; Abouelliel, A.; Sakthikumar, S.; Cuomo, C.A.; Zeng, Q.; Wortman, J.; Young, S.K.; et al. Pilon: An integrated tool for comprehensive microbial variant detection and genome assembly improvement. PLoS ONE 2014, 9, e112963. [CrossRef]

40. Altschul, S.F.; Madden, T.L.; Schaffer, A.A.; Zhang, J.H.; Zhang, Z.; Miller, W.; Lipman, D.J. Gapped BLAST and PSI-BLAST-A new generation of protein database search programs. Nucleic Acids Res. 1997, 25, 3389-3402. [CrossRef]

41. Aboul-Soud, M.A.; Yun, B.W.; Harrier, L.A.; Loake, G.J. Transformation of Fusarium oxysporum by particle bombardment and characterisation of the resulting transformants expressing a GFP transgene. Mycopathologia 2004, 158, 475-482. [CrossRef]

42. Lorang, J.M.; Tuori, R.P.; Martinez, J.P.; Sawyer, T.L.; Redman, R.S.; Rollins, J.A.; Wolpert, T.J.; Johnson, K.B.; Rodriguez, R.J.; Dickman, M.B.; et al. Green fluorescent protein is lighting up fungal biology. Appl. Environ. Microbiol. 2001, 67, 1987-1994. [CrossRef] [PubMed]

43. Maor, R.; Puyesky, M.; Horwitz, B.A.; Sharon, A. Use of green fluorescent protein (GFP) for studying development and fungal plant interaction in Cochliobolus heterostrophus. Mycol. Res. 1998, 102, 491-496. [CrossRef]

44. Spellig, T.; Bottin, A.; Kahmann, R. Green fluorescent protein (GFP) as a new vital marker in the phytopathogenic fungus Ustilago maydis. Mol. Gen. Genet. MGG 1996, 252, 503-509. [PubMed]

45. Eckert, M.; Maguire, K.; Urban, M.; Foster, S.J.; Fitt, B.; Lucas, J.; Hammond-Kosack, K. Agrobacterium tumefaciens-mediated transformation of Leptosphaeria spp. and Oculimacula spp. with the reef coral gene DsRed and the jellyfish gene gfp. FEMS Microbiol. Lett. 2005, 253, 67-74. [CrossRef] [PubMed] 
46. Knight, C.J.; Bailey, A.M.; Foster, G.D. Agrobacterium-mediated transformation of the plant pathogenic fungus Verticillium albo-atrum. J. Plant Pathol. 2009, 91, 745-750.

47. Paparu, P.; Macleod, A.; Dubois, T.; Coyne, D.; Viljoen, A. Efficacy of chemical and fluorescent protein markers in studying plant colonization by endophytic non-pathogenic Fusarium oxysporum isolates. BioControl 2009, 54, 709-722. [CrossRef]

48. Nahalkova, J.; Fatehi, J. Red fluorescent protein (DsRed2) as a novel reporter in Fusarium oxysporum $f . s p$. lycopersici. FEMS Microbiol. Lett. 2003, 225, 305-309. [CrossRef]

49. Elliott, G.; McGrath, J.; Crockett-Torabi, E. Green fluorescent protein: A novel viability assay for cryobiological applications. Cryobiology 2000, 40, 360-369. [CrossRef]

50. Rouws, L.F.M.; Meneses, C.H.S.G.; Guedes, H.V.; Vidal, M.S.; Baldani, J.I.; Schwab, S. Monitoring the colonization of sugarcane and rice plants by the endophytic diazotrophic bacterium Gluconacetobacter diazotrophicus marked with $g f p$ and gusA reporter genes. Lett. Appl. Microbiol. 2010, 51, 325-330. [CrossRef]

51. Covert, S.F.; Kapoor, P.; Lee, M.H.; Briley, A.; Nairn, C.J. Agrobacterium tumefaciens-mediated transformation of Fusarium circinatum. Mycol. Res. 2001, 105, 259-264. [CrossRef]

52. Khang, C.H.; Park, S.Y.; Lee, Y.H.; Kang, S. A dual selection based, targeted gene replacement tool for Magnaporthe grisea and Fusarium oxysporum. Fungal Genet. Biol. 2005, 42, 483-492. [CrossRef] [PubMed]

53. Talhinhas, P.; Muthumeenakshi, S.; Neves-Martins, J.; Oliveira, H.; Sreenivasaprasad, S. Agrobacterium-mediated transformation and insertional mutagenesis in Colletotrichum acutatum for investigating varied pathogenicity lifestyles. Mol. Biotechnol. 2008, 39, 57-67. [CrossRef] [PubMed]

54. Pöggeler, S.; Masloff, S.; Hoff, B.; Mayrhofer, S.; Kück, U. Versatile EGFP reporter plasmids for cellular localization of recombinant gene products in filamentous fungi. Curr. Genet. 2003, 43, 54-61. [CrossRef] [PubMed]

55. De Silva, A.P.; Bolton, M.D.; Nelson, B.D. Transformation of Sclerotinia sclerotiorum with the green fluorescent protein gene and fluorescence of hyphae in four inoculated hosts. Plant Pathol. 2009, 58, 487-496. [CrossRef]

56. Yang, Q.; Yang, L.; Liu, P.G.; Li, S.; Song, J. Agrobacterium tumefaciens-mediated transformation of Trichoderma harzianum. KMITL Sci. Technol. 2007, 7, 185. [CrossRef]

57. Sebastianes, F.L.; Lacava, P.T.; Fávaro, L.C.; Rodrigues, M.B.; Araújo, W.L.; Azevedo, J.L.; Pizzirani-Kleiner, A.A. Genetic transformation of Diaporthe phaseolorum, an endophytic fungus found in mangrove forests, mediated by Agrobacterium tumefaciens. Curr. Genet. 2012, 58, 21-33. [CrossRef]

58. Lee, M.H.; Bostock, R.M. Agrobacterium T-DNA-mediated integration and gene replacement in the brown rot pathogen Monilinia fructicola. Curr. Genet. 2006, 49, 309-322. [CrossRef]

59. Germaine, K.; Keogh, E.; Garcia-Cabellos, G.; Borremans, B.; van der Lelie, D.; Barac, T.; Oeyen, L.; Vangronsveld, J.; Moore, F.P.; Moore, E.R.B.; et al. Colonisation of poplar trees by gfp expressing bacterial endophytes. FEMS Microbiol. Ecol. 2004, 48, 109-118. [CrossRef]

60. Christensen, M.J.; Simpson, W.R.; Al Samarrai, T. Infection of tall fescue and perennial ryegrass plants by combinations of different Neotyphodium endophytes. Mycol. Res. 2000, 104, 974-978. [CrossRef]

61. Wille, P.A.; Aeschbacher, R.A.; Boller, T. Distribution of fungal endophyte genotypes in doubly infected host grasses. Plant J. 1999, 18, 349-358. [CrossRef]

62. Oberhofer, M.; Leuchtmann, A. Horizontal transmission, persistence and competition capabilities of Epichloë endophytes in Hordelymus europaeus grass hosts using dual endophyte inocula. Fungal Ecol. 2014, 11, 37-49. [CrossRef]

63. Shilo, S.; Tripathi, P.; Melamed-Bessudo, C.; Tzfadia, O.; Muth, T.R.; Levy, A.A. T-DNA-genome junctions form early after infection and are influenced by the chromatin state of the host genome. PLoS Genet. 2017, 13, e1006875. [CrossRef] [PubMed]

64. Gang, H.; Liu, G.; Zhang, M.; Zhao, Y.; Jiang, J.; Chen, S. Comprehensive characterisation of T-DNA integration induced chromosomal rearrangement in a birch T-DNA mutant. BMC Genom. 2019, $20,311$. [CrossRef] [PubMed]

65. Kemppainen, M.; Duplessis, S.; Martin, F.; Pardo, A.G. T-DNA insertion, plasmid rescue and integration analysis in the model mycorrhizal fungus Laccaria bicolor. Microb. Biotechnol. 2008, 1, 258-269. [CrossRef] [PubMed]

66. Michielse, C.; Ran, A.; van den Hondel, C. The Aspergillus nidulans amdS gene as a marker for the identification of multicopy T-DNA integration events in Agrobacterium-mediated transformation of Aspergillus awamori. Curr. Genet. 2004, 45, 399-403. [CrossRef] [PubMed] 
67. Blaise, F.; Rémy, E.; Meyer, M.; Zhou, L.; Narcy, J.P.; Roux, J.; Balesdent, M.H.; Rouxel, T. A critical assessment of Agrobacterium tumefaciens-mediated transformation as a tool for pathogenicity gene discovery in the phytopathogenic fungus Leptosphaeria maculans. Fungal Genet. Biol. 2007, 44, 123-138. [CrossRef]

68. Schouten, H.J.; Vande Geest, H.; Papadimitriou, S.; Bemer, M.; Schaart, J.G.; Smulders, M.J.M.; Perez, G.S.; Schijlen, E. Re-sequencing transgenic plants revealed rearrangements at T-DNA inserts, and integration of a short T-DNA fragment, but no increase of small mutations elsewhere. Plant Cell Rep. 2017, 36, 493-504. [CrossRef]

69. Guo, B.; Guo, Y.; Hong, H.; Qiu, L.J. Identification of genomic insertion and flanking sequence of G2-EPSPS and GAT transgenes in soybean using whole genome sequencing method. Front. Plant Sci. 2016, 7, 1009. [CrossRef]

70. Winter, D.J.; Ganley, A.R.D.; Young, C.A.; Liachko, I.; Schardl, C.L.; Dupont, P.Y.; Berry, D.; Ram, A.; Scott, B.; Cox, M.P. Repeat elements organise 3D genome structure and mediate transcription in the filamentous fungus Epichloë festucae. PLoS Genet. 2018, 14, e1007467. [CrossRef]

71. Chujo, T.; Lukito, Y.; Eaton, C.J.; Dupont, P.Y.; Johnson, L.J.; Winter, D.; Cox, M.P.; Scott, B. Complex epigenetic regulation of alkaloid biosynthesis and host interaction by heterochromatin protein I in a fungal endophyte-plant symbiosis. Fungal Genet. Biol. 2019, 125, 71-83. [CrossRef]

72. Kunitake, E.; Tani, S.; Sumitani, J.I.; Kawaguchi, T. Agrobacterium tumefaciens-mediated transformation of Aspergillus aculeatus for insertional mutagenesis. AMB Express 2011, 1, 46. [CrossRef] [PubMed]

73. Mullins, E.D.; Chen, X.; Romaine, P.; Raina, R.; Geiser, D.M.; Kang, S. Agrobacterium-mediated transformation of Fusarium oxysporum: An efficient tool for insertional mutagenesis and gene transfer. Phytopathology 2001, 91, 173-180. [CrossRef] [PubMed]

74. Combier, J.P.; Melayah, D.; Raffier, C.; Gay, G.; Marmeisse, R. Agrobacterium tumefaciens-mediated transformation as a tool for insertional mutagenesis in the symbiotic ectomycorrhizal fungus Hebeloma cylindrosporum. FEMS Microbiol. Lett. 2003, 220, 141-148. [CrossRef]

75. Choi, J.; Park, J.; Jeon, J.; Chi, M.H.; Goh, J.; Yoo, S.Y.; Jung, K.; Kim, H.; Park, S.Y.; Rho, H.S.; et al. Genome-wide analysis of T-DNA integration into the chromosomes of Magnaporthe oryzae. Mol. Microbiol. 2007, 66, 371-382. [CrossRef]

76. Hooykaas, P.J.J.; van Heusden, G.P.H.; Niu, X.; Reza Roushan, M.; Soltani, J.; Zhang, X.; van der Zaal, B.J. Agrobacterium-Mediated Transformation of Yeast and Fungi. In Agrobacterium Biology: From Basic Science to Biotechnology; Gelvin, S.B., Ed.; Springer International Publishing: Cham, Switzerland, 2018; pp. 349-374.

77. Kleinboelting, N.; Huep, G.; Appelhagen, I.; Viehoever, P.; Li, Y.; Weisshaar, B. The structural features of thousands of T-DNA insertion sites are consistent with a double-strand break repair-based insertion mechanism. Mol. Plant 2015, 8, 1651-1664. [CrossRef]

78. Jia, Q.; Bundock, P.; Hooykaas, P.J.J.; de Pater, S. Agrobacterium tumefaciens T-DNA integration and gene targeting in Arabidopsis thaliana non-homologous end-joining mutants. J. Bot. 2012, 2012, 13. [CrossRef]

79. Kim, S.; No, V.; Gelvin, S. Genome-wide analysis of Agrobacterium T-DNA integration sites in the Arabidopsis genome generated under non-selective conditions. Plant J. Cell Mol. Biol. 2007, 51, 779-791. [CrossRef]

(C) 2019 by the authors. Licensee MDPI, Basel, Switzerland. This article is an open access article distributed under the terms and conditions of the Creative Commons Attribution (CC BY) license (http://creativecommons.org/licenses/by/4.0/). 